\title{
LOUVAIN NATURAL RADIOCARBON MEASUREMENTS II
}

\author{
J. M. DEUMER, E. GILOT and P. C. CAPRON
}

Department of Nuclear Chemistry, University of Louvain, Louvain, Belgium

The measurements reported in this list were made in the Louvain $\mathrm{C}^{14}$ dating laboratory from July 1962 to October 1963.

\section{INTRODUCTION}

The $\mathrm{C}^{14}$ dates given below are a continuation of the work presented in our first list (Louvain I). Sample preparation, counting procedure and calculations were obtained by using a $0.6 \mathrm{~L} \mathrm{CH}_{4}$ proportional counter, operating at $3 \mathrm{~atm}$ pressure. Each sample was measured at least twice for a counting period of 21 $\mathrm{hr}$ at a minimum time of 30 days after combustion. Our standard samples for calibration are 63-yr-old oak tree samples. These, when corrected for age, have $\mathrm{C}^{14}$ contents equal to $94 \%$ of the NBS oxalic-acid standard. Data have been calculated on the basis of a $\mathrm{C}^{14}$ half life of $5570 \mathrm{yr}$ in agreement with the decision of the Fifth Radiocarbon Dating Conference (Godwin, 1962) and expressed in years B.P. (before A.D. 1950) and also in terms of the Christian calendar.

The error in the given ages includes experimental standard deviation resulting from the counting of the modern standard, of the unknown sample and of the background corrections (Crèvecoeur, Vander Stricht and Capron, 1959).

By the decision taken at the Fifth Radiocarbon Dating Conference (Cambridge, July 22-26, 1962), all dates and $\mathrm{C}^{14}$ measurements are to be reported in terms of the Libby half life, $5570 \mathrm{yr}$. In order to prevent confusion we give here all data, found on the basis of the Libby half life, for samples referred to in Louvain I. In the latter paper dates were based on the NBS half life of $\mathrm{C}^{14}$ (5760 yr).

$\begin{array}{lcc}\text { Lab. no. } & \text { Corrected age according to Libby half life } \\ \text { Lv } 100 & 11,250 \pm 240 & 9300 \text { B.c. } \\ \text { Lv } 101 & 11,900 \pm 330 & 9950 \text { B.c. } \\ \text { Lv } 6 & 10,040 \pm 400 & 8090 \text { B.c. } \\ \text { Lv } 56 & 1090 \pm 180 & \text { A.D. } 860 \\ \text { Lv } 73 & 10,560 \pm 520 & 8610 \text { B.c. } \\ \text { Lv } 74 & 11,550 \pm 410 & 9600 \text { B.c. } \\ \text { Lv } 75 N & 11,750 \pm 400 & 9800 \text { B.c. } \\ \text { Lv } 75 & 10,340 \pm 450 & 8390 \text { B.c. } \\ \text { Lv } 10 & 3940 \pm 150 & 1990 \text { B.c. } \\ \text { Lv } 43 & 840 \pm 130 & \text { A.D. } 1110 \\ \text { Lv } 44 & >30,000 & 3880 \text { B.c. } \\ \text { Lv } 45 & 5830 \pm 180 & 1030 \text { B.C. } \\ \text { Lv } 46 & 2980 \pm 160 & \\ \text { Lv } 47 & >30,000 & \text { A.D. } 240 \\ \text { Lv } 54 & 1710 \pm 100 & 710 \text { B.C. }\end{array}$




\section{ACK NOWLEDGMENTS}

The participation of N. Ancion in the operations of the laboratory and the maintenance of electronics by G. Michotte and B. Pirotte are gratefully acknowledged. The description of each sample is based on information provided at the time of application by the person submitting the sample to the laboratory. Financial support was provided by the "Institut Interuniversitaire des Sciences Nucléaires."

\section{SAMPLE DESCRIPTIONS}

I. GEOLOGIC SAMPLES

$680 \pm 160$

\section{Lv 27. Vuylbeek}

A.D. 1270

Charcoal from charcoal layer, $10 \mathrm{~cm}$ thick, at depth of $40 \mathrm{~cm}$ below surface, at the Forêt de Soignes $\left(50^{\circ} 47^{\prime} \mathrm{N}\right.$ Lat, $4^{\circ} 24^{\prime} \mathrm{E}$ Long), Prov. of Brabant, Belgium. Charcoal is between two layers of alluvium in the valley of a tributary to the Vuylbeek. Coll. 1962 and subm. by O. De Bontridder, Univ. of Louvain. The measurement allows the dating of a new erosion period of the river.

\section{Tourbière du Grand Passage series}

Peat from Tourbière du Grand Passage, near Les Tailles $\left(50^{\circ} 17^{\prime} 31^{\prime \prime} \mathrm{N}\right.$ Lat, 5० 45' 12" E Long), Prov. of Luxembourg, Belgium, alt 605 m. Coll. 1962 and subm. by W. Mullenders, Univ. of Louvain, Lab. of Palynology.

\section{Lv 57. Grand Passage $25 \mathrm{~cm}$}

Peat from $25 \mathrm{~cm}$, Sub-Atlantic horizon. Pollen analysis indicates the 3rd beech maximum (Fagus silvatica-F III), shown in published pollen diagram (Mullenders and Knop, 1962). This maximum had not yet been dated in Belgium.

\section{Lv 58. Grand Passage $110 \mathrm{~cm}$}

$$
1100 \pm 90
$$

Peat from $110 \mathrm{~cm}$, Sub-Atlantic horizon. Pollen analysis indicates a level between two beech increases (Fagus silvatica), the 2nd and 3rd maximum (F II and F III) (Mullenders and Knop, 1962).

\section{Lv 59. Grand Passage $155 \mathrm{~cm}$}

$2770 \pm 100$

820 B.C.

Peat from $155 \mathrm{~cm}$, Sub-Boreal level. Pollen analysis indicates a level (about $350 \mathrm{~cm}$ in the diagram of Mullenders and Knop, 1962) between the 4th and 5th hazel maxima (Corylus avellana-C III and C IV).

\section{Lv 60. Grand Passage $155 \mathrm{~cm}$}

$2790 \pm 90$

This sample is taken from the same level as Lv 59 .

\section{Col de la Furka series}

Peat from alt $2280 \mathrm{~m}$, Col de la Furka, Aelpetli $\left(46^{\circ} 37^{\prime} \mathrm{N}\right.$ Lat, $8^{\circ} 27^{\prime} \mathrm{E}$ Long), near Realp, Canton of Uri, Switzerland. Coll. 1962 and subm. by W. Mullenders. Site is above present-day tree line; pollen analysis shows that it was already above tree line at the times of the dates, but does not indicate possible fluctuations of forest limits. 


\section{Lv 66. Col de la Furka $40 \mathrm{~cm}$}

Peat from $40 \mathrm{~cm}$ below ground surface, limit Sub-Boreal-Sub-Atlantic.

Lv 67. Col de la Furka $60 \mathrm{~cm}$

Peat from $60 \mathrm{~cm}$ below ground surface, Sub-Boreal level.

\section{Darse 5 series}

Peat from Darse 5, Polder Austruweel (51 $14^{\prime} 46^{\prime \prime} \mathrm{N}$ Lat, $4^{\circ} 24^{\prime} 30^{\prime \prime} \mathrm{E}$ Long), Prov. of Antwerp, Belgium. Coll. 1959 and subm. by W. Mullenders.

\section{Lv 94. Darse 5, $162 \mathrm{~cm}$}

Peat from $162 \mathrm{~cm}$ below ground surface, Sub-Boreal level. $\mathrm{C}^{14}$ date agrees with the pollen analysis.

\section{Lv 95. Darse 5, $175-180 \mathrm{~cm}$}

Peat from 175 to $180 \mathrm{~cm}$, Sub-Boreal level. Date corrects the palynological interpretation which assigned an older age to that level.

\section{Lv 96. Darse 5, $230 \mathrm{~cm}$ \\ $3890 \pm 150$ \\ 1940 B.C.}

Peat from $230 \mathrm{~cm}$, limit Atlantic-Sub-Boreal. Date shows that the hazel maximum (Corylus avellana) at $230 \mathrm{~cm}$ is the 4 th maximum (C III).

\section{Lv 108. Darse 5, $263 \mathrm{~cm}$}

$5160 \pm 160$

3210 B.C.

Peat from $263 \mathrm{~cm}$, Atlantic level. Date shows that hazel increase (Corylus avellana) at level $263 \mathrm{~cm}$ is the 3rd maximum (CX). The decrease of Ulmus, characteristic of that period in other parts of NW Europe, is not observed here.

\section{Lommel series}

Peat layer from 200 to $210 \mathrm{~cm}$ below surface of plain of Weyerkense Bergen $\left(51^{\circ} 15^{\prime} \mathrm{N}\right.$ Lat, $5^{\circ} 18^{\prime} \mathrm{E}$ Long), near Lommel, Prov. of Limbourg, Belgium, alt $46 \mathrm{~m}$. Overlies frost contorted sand correlated with the Würm glacial age; overlain by eolian sand of Younger Dryas and Holocene ages. Coll. 1963 and subm. by W. Mullenders. Pollen analysis indicates a temperate climate between two cold periods; the oscillation is incontestably Tardiglacial, but could imply either Bölling or Alleröd. The $\mathrm{C}^{14}$ dating shows it to be Alleröd (Gullentops, Mullenders, Deumer and Gilot, in preparation). The dates agree with Lv 100 and Lv 101 (Louvain I) from the same locality.

\section{Lv 102. Lommel $210 \mathrm{~cm}$}

$$
11,680 \pm 240
$$

Peat from $210 \mathrm{~cm}$, taken from same level as Lv 101.

\section{Lv 103. Lommel $200 \mathrm{~cm}$}

Peat from $200 \mathrm{~cm}$, taken from same much too young; contamination by roots is assumed.

\section{Alpes de Venose series}

Peat overlying gyttja from Venosc $\left(45^{\circ} 00^{\prime} \mathrm{N}\right.$ Lat, $6^{\circ} 07^{\prime} \mathrm{E}$ Long), in French Alps, alt 1644 m. Coll. 1962 and subm. by Couteaux, Univ. of Louvain, 
Lab. of Palynology. By pollen analysis, layer was dated as Alleröd, but with substantial reservations (Couteaux, 1962); the curve of Cyperaceae pollen was thought to be possibly misleading, as were earlier data of local literature. $\mathrm{C}^{14}$ dates indicate an early Pre-Boreal age.

\section{Lv 106. Venose $175-181 \mathrm{~cm}$}

$10,130 \pm 250$

Peat from 175 to $181 \mathrm{~cm}$.

\section{Lv 107. Venose 181-187 $\mathrm{cm}$}

Peat from 181 to $187 \mathrm{~cm}$.

\section{Terneuzen series}

Peat and wood from fossil pine stand covered by Sub-Boreal peat, $150 \mathrm{~cm}$ thick, and then by Sub-Atlantic clay, $100 \mathrm{~cm}$ thick, Terneuzen $\left(51^{\circ} 19^{\prime} \mathrm{N}\right.$ Lat, $3^{\circ} 48^{\prime}$ E Long), Zealand Flanders, The Netherlands. Coll. 1962 and subm. by Munaut, Univ. of Louvain, Lab. of Palynology and Dendrochronology.

\section{Lv 114. Terneuzen pine}

Wood from pine stub in situ (Pinus sylvestris, id. by E. Frison) in peat at $180 \mathrm{~cm}$ below ground surface.

\section{Lv 115. Terneuzen pine}

$4380 \pm 120$

Wood from pine stub in situ (Pinus sylvestris, id. by E. Frison) in peat at $180 \mathrm{~cm}$ below ground surface. Dendrochronology indicates that the two pines ( Lv 114 and Lv 115) are contemporary.

\section{Lv 116. Terneuzen $110-115 \mathrm{~cm}$}

$4280 \pm 130$

$$
2330 \text { в.c. }
$$

Peat from 110 to $115 \mathrm{~cm}$ below surface of peat layer. Presence of upper part of Pinus zone shows sample to be Sub-Boreal, in agreement with Lv 114 and $\operatorname{Lv} 115$.

\section{Lv 117. Terneuzen 0-10 $\mathrm{cm}$}

Peat from 0 to $10 \mathrm{~cm}$ below surface of peat layer. Date agrees with pollen analysis in giving a late Sub-Boreal age.

\section{Lv 118. Terneuzen $51-58 \mathrm{~cm}$}

$$
3500 \pm 110
$$

Peat from 51 to $58 \mathrm{~cm}$ below surface of peat layer. The decrease of Ulmus observed at this level is not correlative with the classical decrease, dated at 3000 B.c. in many localities.

\section{Lv 119. Terneuzen oak}

$4150 \pm 90$

\section{0 в.c.}

Wood from oak stub in situ (Quercus, id. by E. Frison) in peat $180 \mathrm{~cm}$ below ground surface. The small stratigraphic difference seen between the oak and the two pines (Lv 114 and Lv 115) is evidently not significant.

\section{Lv 120. Terneuzen oak}

Wood from oak trunk (Quercus, id. by E. Frison) from peat $180 \mathrm{~cm}$ below ground surface. 
II. ARCHAEOLOGIC SAMPLES

\section{Lv 8. Waha}

Burned wood from the construction of the St. Etienne Church Waha $\left(50^{\circ}\right.$ $13^{\prime} \mathrm{N}$ Lat, 5 $20^{\prime} \mathrm{E}$ Long), Prov. of Luxembourg, Belgium. Coll. 1957 and subm. by J. Mertens, Service des Fouilles, Bruxelles. This church dates, according to the historians, from A.D. 1050 (Mertens, 1957).

\section{Lv 11. Via Mansuerisca}

$$
790 \pm 70
$$

Wood from the Via Mansuerisca the Hautes Faones $\left(50^{\circ} 31^{\prime}\right.$ N Lat, $6^{\circ}$ Mertens, Selgium. Subm. by J. , Service des Fouilles, Bruxelles, to help fix the controversial age of this road (Bastin, 1935; Dricot, 1960; Louvain I: Lv 10).

\section{Lv 17. Congo 1}

$7840 \pm 190$

5890 в.c.

Fossil wood from dried-out fen, coll. during construction of a road at Lemba ( $4^{\circ} 23^{\prime} \mathrm{S}$ Lat, $15^{\circ} 20^{\prime} \mathrm{E}$ Long), Prov. of Leopoldville, Congo. Coll. 1957 and subm. by W. Van Pée, Lovanium Univ., Leopoldville, Congo. Comment: date indicates a time when the site, presently a desert, was occupied by equatorial forest.

\section{Faascht III series}

Wood samples, id. by J. Heim, from road supposed to be Roman, at Grendel ( $49^{\circ} 44^{\prime} \mathrm{N}$ Lat, $5^{\circ} 48^{\prime} \mathrm{E}$ Long), Prov. of Luxembourg, Belgium, 50 cm below surface. Coll. 1962 and subm. by Couteaux. Pollen analysis shows at this horizon, a period which can be either Roman or recent. $\mathrm{C}^{14}$ dates undoubtedly indicate recent period.

\section{Lv 20. Fir wood (Abies) \\ Lv 21. Pine wood (Pinus) \\ Lv 22. Pine wood (Pinus)}

\section{Busenol series}

Samples from site rich in archaeological remains at Busenol $\left(49^{\circ} 38^{\prime} \mathrm{N}\right.$ Lat, 5 $36^{\prime}$ E Long), Prov. of Luxembourg, Belgium. Coll. 1958 and subm. by J. Mertens, Service des Fouilles, Bruxelles.

\section{Lv 23. Tr XXVIII}

$1950 \pm 110$

Wood from pre-Roman rampart.

$$
1 \text { B.C. }
$$

\section{Lv 24. Tr XXIII}

$$
\text { A.D. } 1020
$$

$$
930 \pm 110
$$

Charcoal from a burned horizon, remains of medieval dungeon.

\section{Lv 25. Tr XXIII}

$1040 \pm 90$

Charcoal from same level as Lv 24.

\section{A.D. 910}


Charcoal from St. Hubert Abbey at St. Hubert $\left(50^{\circ} 01^{\prime} \mathrm{N}\right.$ Lat, $5^{\circ} 22^{\prime} \mathrm{E}$ Long), Prov. of Luxembourg, Belgium. Coll. 1957 and subm. by J. Mertens, Service des Fouilles, Bruxelles. Date gives the first occupation age of the St. Hubert site.

\section{Bruges series}

Peat from horizon below oldest occupation level at Bruges $\left(51^{\circ} 13^{\prime} \mathrm{N}\right.$ Lat, $3^{\circ} 14^{\prime}$ E Long), Prov. of West Flanders, Belgium. Coll. 1955 and subm. by J. Mertens, Service des Fouilles, Bruxelles (Mertens, in preparation; Louvain I: Lv 43).

\section{Lv 38. Bruges 1}

Pollen analysis by W. Mullenders shows the site to have been forested, with much lime (Tilia), corresponding to the Atlantic zone.

\section{Lv 39. Bruges 2}

$1160 \pm 110$

Pollen analysis at this level by W. Mullenders shows deforestation accompanied by very extensive agricultural activity.

\section{Lv 42. Orval}

$$
690 \pm 150
$$

Wood from a construction earlier than Orval abbey near Villers-devantOrval (49 $38^{\prime} \mathrm{N}$ Lat, $5^{\circ} 21^{\prime}$ E Long), Prov. of Luxembourg, Belgium. Coll. 1962 and subm. by J. Mertens, Service des Fouilles, Bruxelles.

\section{Lv 48. Alba}

$$
2040 \pm 160
$$

90 B.C.

Charcoal from Hercules temple at Massa d'Albe $\left(42^{\circ} 05^{\prime} \mathrm{N}\right.$ Lat, $13^{\circ} 25^{\prime}$ E Long), Prov. of Aquila, Italy. Coll. 1962 and subm. by J. Mertens, Univ. of Louvain. Date confirms archaeological date: 1st half of lst century B.C. (De Visscher, Mertens and Balty, 1962).

\section{Lv 50. Bouillon}

Wood from cross in feudal castle at Bouillon $\left(49^{\circ} 47^{\prime} \mathrm{N}\right.$ Lat, $5^{\circ} 04^{\prime} \mathrm{E}$ Long), Prov. of Luxembourg, Belgium. Coll. 1961 and subm. by J. Mertens, Univ. of Louvain. Date definitively shows the cross to have no bearing on the history of the castle.

\section{Lv 53. Perk}

Wood from road $1.75 \mathrm{~m}$ below surface at Perk $\left(50^{\circ} 57^{\prime} \mathrm{N}\right.$ Lat, $4^{\circ} 30^{\prime} \mathrm{E}$ Long), Prov. of Brabant, Belgium. Coll. 1951 and subm. by J. Mertens, Univ. of Louvain. Date shows an important alluvium in this site.

\section{Lv 65. Mesvin}

Charcoal from Sans Pareil mine $3.65 \mathrm{~m}$ below surface at Mesvin $\left(50^{\circ} 25^{\prime}\right.$ $37^{\prime \prime}$ N Lat, $3^{\circ} 57^{\prime} 58^{\prime \prime}$ E Long), Prov. of Hainaut, Belgium. Coll. and subm. by Moisin, Société de Recherche Préhistorique en Hainaut. $\mathrm{C}^{14}$ dating gives age of mine embankment (Lefrancq et al., 1957). 
Lv 82. Stree

Wood from Roman road at Stree $\left(50^{\circ} 17^{\prime} \mathrm{N}\right.$ Lat, $4^{\circ} 16^{\prime} \mathrm{E}$ Long), Prov. of Hainaut, Belgium. Coll. 1960 and subm. by J. Mertens, Service des Fouilles, Bruxelles. Comment: road is certainly older than the wood, which may have come from recent repair; another sample is needed.

\section{Neuchatel lake series}

To compare difference in time between prehistoric constructions in $\mathrm{S}$ bank and N bank of Neuchatel lake, two samples were coll. (1960) by Grandjean, Prehist. Mus. Neuchatel, and subm. by E. Borel, member of Prehist. Commission Neuchatel Canton.

\section{Lv 87N. Montbec}

$$
\begin{aligned}
& 2930 \pm 120 \\
& 980 \text { в.C. }
\end{aligned}
$$

Wood from piling $1.5 \mathrm{~m}$ below surface of South Neuchatel lake near Chabrey $\left(46^{\circ} 56^{\prime}\right.$ N Lat, $6^{\circ} 58^{\prime}$ E Long), Canton of Vaud, Switzerland.

\section{Lv 87. Montbec}

$2840 \pm 220$

Sample from same level as Lv $87 \mathrm{~N}$. Comment: no pretreatment.

\section{Lv 88. Champreveyres}

$$
2680 \pm 150
$$

Wood from piling $2 \mathrm{~m}$ below 730 в.c. Blaise $\left(47^{\circ} 03^{\prime} N\right.$ Lat, $6^{\circ} 58^{\prime}$ E Long), Canton of Neuchatel, Switzerland.

\section{Lv 89. Motier}

Wood from tree trunk (fir) used in basement of Motier castle at MotierTravers ( $46^{\circ} 55^{\prime} \mathrm{N}$ Lat, $6^{\circ} 37^{\prime}$ E Long), Canton of Neuchatel, Switzerland. Date shows absence of construction before the recent castle.

\section{Lv 93 bis. Deir el Bahari}

Wood from lid of Egyptian mummiform coffin, from $\mathbf{8 5 0}$ в.c.

Thebes (Luxor) Egypt. Coll. by Musee Biblique Inst. d'Archéologie, Univ of Louvain; subm. by J. Mertens. Comment: sample not pretreated. Measurement repeated to test reliability of the dates from Louvain I ( $\operatorname{Lv}$ 93: $2750 \pm 210$ 800 B.c.).

Date lists:

$$
\text { REFERENCES }
$$

Louvain I Dossin, Deumer and Capron, 1962

Bastin, J. (abbé), 1935, La Via Mansuerisca: Spa Editions "J'ose", 15 p.

Couteaux, M., 1962, Analyse pollinique d'une tourbière des Alpes Méridionales françaises: Alpe de Venosc $1644 \mathrm{~m}$ : Pollen et Spores, v. 4, no. 1, p. 111-120.

Crèvecoeur, E. H., Vander Stricht, A., and Capron, P. C., 1959, Precision of the dating method. Standardization of the calculation of the errors and the maximum age in the $\mathrm{C}^{14}$ method: Acad. Royale Belgique Bull. Cl. Sci., v. 45, p. 876-890.

Dricot, E. M., 1960, Recherches palynologiques sur le plateau des Hautes Fagnes: Soc. Royale de Bot. Belgique Bull., v. 92, p. 157-196.

De Visscher, F., Mertens, J., Balty, C., 1962, Le sanctuaire d'Hercule et ses portiques à Alba Fucens: Monumenti Antichi, v. 46, p. 376.

Godwin, H., 1962, Half-life of radiocarbon: Nature, v. 195, no. 4845, p. 984

Lefrancq et al., 1957, Fouilles S.R.P.H.

Mertens, J., 1957, L'Eglise St. Etienne à Waha: Ardenne et Famenne, v. 1, no. 19, p. 114.

Mullenders, W., Knop, C., 1962, La tourbière du Grand-Passage: Soc. Royale de Bot. Belgique Bull., v. 94, p. 163-175. 